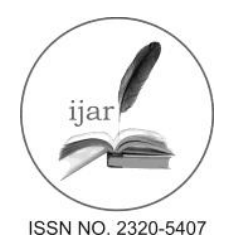

Journal homepage:http://www.journalijar.com
Journal DOI:10.21474/IJAR01

RESEARCH ARTICLE

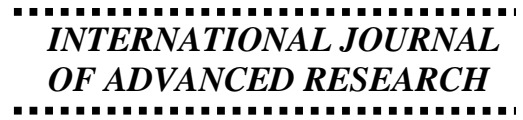

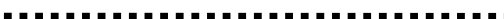

\title{
TO EVALUATE THE STATUS OF SERUM VITAMIN D IN CHRONIC MYELOID LEUKEMIA.
}

Veena Singh Ghalaut ${ }^{1}$, Rajender Kumar ${ }^{2}$, Asha Kumari ${ }^{3}$, Sumit Dokwal ${ }^{4}$ and Madhumita Sarkar ${ }^{5}$.

1. Sr. Prof.\& Head of Department Biochemistry, Pt. BD Sharma Post graduate Institute of Medical Sciences Rohtak, Haryana, India.

2. Post Graduate student Biochemistry, Pt. BD Sharma Post graduate Institute of Medical Sciences Rohtak, Haryana, India.

3. Demonstrator, Pt. BD Sharma Post graduate Institute of Medical Sciences Rohtak, Haryana, India.

4. Assist. Prof., Pt. BD Sharma Post graduate Institute of Medical Sciences Rohtak, Haryana, India.

5. Post Graduate student Biochemistry, Pt. BD Sharma Post graduate Institute of Medical Sciences Rohtak, Haryana, India.

\section{Manuscript Info}

Manuscript History:

Received: 18 March 2016

Final Accepted: 22 April 2016

Published Online: May 2016

Key words:

Vitamin D, CML, Cancer.

*Corresponding Author

Asha Kumari

\section{Abstract}

Introduction: Recently data accruing has suggested some links between Vit $\mathrm{D}$ and occurrence of Cancer. Studies have presented controversial results. So this study was planned to analyze the link between Vit D and Chronic Myeloid Leukemia.

Aims and objectives:

1. To evaluate the status of serum vitamin $\mathrm{D}$, in twenty five diagnosed CML patients.

2. To compare the status of serum vitamin $\mathrm{D}$, with twenty five age and sex matched healthy controls.

Patients and controls were categorized into two groups.

Group I: Diagnosed cases with CML.

Group II: Control group- age and sex matched healthy volunteers.

Material and methods: In this present study twenty five patients of diagnosed CML and twenty five age and sex matched healthy controls were enrolled for the study. The diagnosis in cases was made by history, clinical examination, total and differential leukocyte count, bone marrow examination and cytogenetic studies. Serum vitamin D levels were estimated by a commercial enzyme linked immunosorbent assay kit for human vitamin D

Results and observations:In the present study mean serum vitamin D level in group I was $23.04 \pm 7.95 \mathrm{ng} / \mathrm{ml}$. In group II, mean serum vitamin D level was $23.75 \pm 8.65 \mathrm{ng} / \mathrm{ml}$ (range 8.07 to $44.11 \mathrm{ng} / \mathrm{ml}$ ). In males, mean serum vitamin D level in group I was $24.5 \pm 8.5 \mathrm{ng} / \mathrm{ml}$ and in group II $24.3 \pm 10.7$ $\mathrm{ng} / \mathrm{ml}$. In females, mean serum vitamin D level in group I was $21.9 \pm 7.5$ $\mathrm{ng} / \mathrm{ml}$ and in group II $23.2 \pm 7.0 \mathrm{ng} / \mathrm{ml}$.

Conclusion:There was no significant correlation observed between Vit D levels and CML.

Copy Right, IJAR, 2016. All rights reserved.

\section{Introduction:-}

Chronic myeloid leukemia (CML) is a relatively rare disease with a worldwide annual incidence rate ranging from less than 1.0 to 2.0 per 100,000 persons. It is slightly more common in males than in females. ${ }^{[1]} \mathrm{CML}$ originates in a pluripotent hematopoietic stem cells of the bone marrow and is characterized by greatly increased numbers of granulocytes in the blood. Myeloid and other hematopoietic cell lineages are involved in the process of clonal proliferation and differentiation. ${ }^{[2]}$ 
Vitamin D is a group of steroids which acts as the primary biological regulators of calcium homeostasis. There are two forms of vitamin $\mathrm{D}$; vitamin $\mathrm{D}_{2}$ (ergocalciferol) comes from irradiation of the yeast and plant sterol ergosterol, and vitamin $\mathrm{D}_{3}$ (cholecalciferol) which is found in oily fish and cod liver oil and is synthesized in the skin. Vitamin D represents vitamin $\mathrm{D}_{2}$ and vitamin $\mathrm{D}_{3}$. Adequate circulating vitamin $\mathrm{D}$ concentrations are critical to maintain the health and the function of the immune, reproductive, muscular, skeletal and integumentary system of men and women of all ages and races. It functions the same way as other steroid hormones by interacting with its cognate vitamin D receptor (VDR). ${ }^{[3]}$

\section{Role of vitamin $d$ in cancer:-}

Calcitriol, besides its activity in suppressing cell growth, is capable of inducing differentiation of human promyelocytic leukemia cells (HL-60) into mature myeloid cells (myelocytes, metamyelocytes and mature granulocytes) ${ }^{[4]}$ The physiologically active metabolite of calcitriol, specifically inhibits the proliferation of U937 cells (human macrophage cell line) whilst inducing the monocyte-related surface antigen CD14 (cluster of differentiation). The failure of other metabolites of calcitriol to induce these changes suggests that the hormone calcitriol mediates these events by high affinity binding to its intracellular receptor.A study reported that prevalence of vitamin D insufficiency in cancer survivors was high but similar to what has been described in the general population. No cancer specific variables were associated with vitamin D insufficiency. Since cancer survivors are at a higher risk for subsequent malignancies, cardiovascular disease, and low bone mineral density, all of which may be affected by vitamin D levels, interventions to improve vitamin D status in this vulnerable population are needed. ${ }^{[5]}$ Another study reported that findings do not support a protective role of high vitamin D concentration in lymphoid cancers overall. However, they suggest that higher concentrations of vitamin D are associated with a reduced risk of CLL. ${ }^{[6]}$

With this background, the present study was planned to analyze vitamin D levels in patients of CML before and after therapy and to compare with healthy controls.

\section{Aims and objectives:-}

1. To evaluate the status of serum vitamin D, in twenty five diagnosed CML patients.

2. To compare the status of serum vitamin $\mathrm{D}$, with twenty five age and sex matched healthy controls.

\section{Material and methods:-}

The present study was conducted in the Department of Biochemistry in collaboration with Department of Medicine (Clinical Hematology unit); Pt. BD Sharma Post Graduate Institute of Medical Sciences, Rohtak.

Twenty five patients of diagnosed chronic myeloid leukemia were enrolled for the study. Twenty five age and sex matched healthy persons were taken as controls. The diagnosis in cases was made by history, clinical examination, total and differential leukocyte count, bone marrow examination and cytogenetic studies. Complete history and physical examination was done in controls and cases. Routine biochemistry, complete haemogram and serum vitamin $\mathrm{D}$ were estimated in diagnosed patients and in controls.

\section{Inclusion criteria:-}

Diagnosed chronic myeloid leukemia patients.

\section{Exclusion criteria:-}

1. Patients on drugs altering vitamin $\mathrm{D}$ levels like antiepileptic drugs, vitamin $\mathrm{D}$ and calcium supplementation etc.

2. Patients suffering from any chronic disease (renal, hepatic disease, endocrine, malignancy) that could affect study participation or confound data interpretation.

3. Those with other risk factors of hypovitaminosis like gastric or bowel resection, malabsorption.

Patients and controls were categorized into two groups.

Group I: Diagnosed cases with CML.

Group II: Control group- age and sex matched healthy volunteers.

\section{Sample collection and storage:-}

Six milliliter of venous blood sample was taken in a plain red capped evacuated blood collection tube under all aseptic precautions. Samples were processed within one hour of collection. Serum was separated by centrifugation at 
$2000 \mathrm{rpm}$ for 10 minutes after clotting. Separated serum was analyzed for routine biochemistry on the same day and stored at $-20^{\circ} \mathrm{C}$ for vitamin $\mathrm{D}$ estimation.

\section{Estimation of serum vitamin d:-}

Serum vitamin D levels were estimated by a commercial enzyme linked immunosorbent assay kit for human vitamin D. ${ }^{[7]}$ Reference range for Vit D was selected (Table 1)

\section{Statistical analysis of data:-}

The data was compiled and analyzed using SPSS statistical package (version 17.0; SPSS Inc. Chicago, IL, USA). Continuous variables were presented as Mean \pm SD and categorical variables were presented as absolute numbers and percentage. Continuous variables were analyzed using paired t-test. For all statistical tests a p value of $<0.05$ was considered as significant.

\section{Results and observations:-}

In the present study mean serum vitamin D level (Figure 2) in group I was 23.04 $7.95 \mathrm{ng} / \mathrm{ml}$ (range 8.74 to 40.92 $\mathrm{ng} / \mathrm{ml}$ ). Out of 25 patients in group I, 10 patients had serum vitamin D levels <20 ng/ml, (Table II) 11 patients had 20 to $30 \mathrm{ng} / \mathrm{ml}$, and 4 patient had serum vitamin D levels 30 to $100 \mathrm{ng} / \mathrm{ml}$. In group II, mean serum vitamin D level was $23.75 \pm 8.65 \mathrm{ng} / \mathrm{ml}$ (range 8.07 to $44.11 \mathrm{ng} / \mathrm{ml}$ ). 8 patients had serum vitamin D levels $<20 \mathrm{ng} / \mathrm{ml}, 12 \mathrm{patients} \mathrm{had}$ 20 to $30 \mathrm{ng} / \mathrm{ml}$, and 5 patients had serum vitamin D levels 30 to $100 \mathrm{ng} / \mathrm{ml}$. (Table II).

In males, mean serum vitamin D level in group I was $24.5 \pm 8.5 \mathrm{ng} / \mathrm{ml}$ and in group II $24.3 \pm 10.7 \mathrm{ng} / \mathrm{ml}$. In females, mean serum vitamin D level in group I was $21.9 \pm 7.5 \mathrm{ng} / \mathrm{ml}$ and in group II $23.2 \pm 7.0 \mathrm{ng} / \mathrm{ml}$. There was no significant correlation observed. (Table III, Table IV)

\section{Discussion:-}

Serum $25(\mathrm{OH}) \mathrm{D}$ is the indicator of vitamin D bioavailability in the body. It has been recommended that serum levels of $25(\mathrm{OH}) \mathrm{D}$ above $30 \mathrm{ng} / \mathrm{ml}$ in children and adults are optimal for gaining all the potential health benefits associated with vitamin D. Regular sun exposure and adequate dietary intake are essential in meeting these recommendations. ${ }^{[8]}$

The median age of presentation in CML is 45 to 55 years, accounting for $20 \%$ of leukemia affecting adults. Age-wise distribution of CML patients in this study is shown in Figure 1. Males are affected more than females in CML, with a 2:1 ratio. ${ }^{[9]}$ The male to female sex ratio varied from 1:08 (Sterlings, Gujarat) to 3:1 (TMH, Mumbai). The median age of the population varied from minimum 32 years (Nizam Institute of medical sciences, Hyderabad, South India) to maximum 42 years (Ashirwadcenter, Mumbai, Southwest India). ${ }^{[10]}$ This decade younger population was the most consistent fact presented in almost all studies confirming that in India, median age at presentation is a decade younger compared with the age presented in European (median age 55 years) as well as in American (median age 66 years) literature. ${ }^{[10]}$ In the present study, the mean age of the study group was $43 \pm 12.8$ years (range 20 to 70 years). Male to female ratio was 1.2:1.3. The mean age of presentation was in accordance with the previous studies, but the sex ratio was not in accordance to previous studies. This may be due to the small sample size or due to geographical differences.

In the present study $88 \%$ in group I and $84 \%$ in group II had serum vitamin D levels less than the sufficient levels. The mean serum vitamin D levels in group I were comparable with mean serum vitamin D levels in group II. There was negative correlation between serum vitamin D levels and age in group I, as the age advances serum vitamin D levels decreases. No other significant correlation was observed. Paired t-test showed, the difference of mean serum vitamin D levels was 0.56 and p-value was 0.79 which was not significant.

In a study conducted by Pardanani ${ }^{[11]}$ and others, they reported that there was no significant correlation between vitamin D insufficiency or severe deficiency and a variety of clinical or laboratory variables in PMF (primary myelofibrosis), myelodysplastic syndrome (MDS) or polycythemia vera (PV). Furthermore vitamin D insufficiency did not influence either overall or leukemia-free survival in PMF, MDS or PV (P > 0.05). While hypovitaminosis D was relatively common in MPN (myeloproliferative neoplasm) and MDS, its clinical relevance for prognosis was limited. ${ }^{[11]}$

Simmonsand others reported that the prevalence of vitamin D insufficiency and deficiency was similar between pediatric ALL (acute lymphocytic leukemia) survivors and healthy US adolescents. There was no difference 
between ALL survivors treated with HCT (hematopoietic cell transplantation) compared with those treated without HCT. A significant percentage of ALL survivors did not attain the RDA (recommended daily allowance) via diet for vitamin D or calcium and those who had HCT generally consumed less dietary vitamin D than those treated with conventional chemotherapy. ${ }^{[12]}$

Choudharyand others reported that the prevalence of vitamin D insufficiency in cancer survivors was high but similar to what has been described in the general population. No cancer specific variables were associated with vitamin D insufficiency. Since cancer survivors are at a higher risk for subsequent malignancies, cardiovascular disease, and low bone mineral density, all of which may be affected by low vitamin D levels, interventions to improve vitamin D status in this vulnerable population are needed. ${ }^{[13]}$

Luczynskaand others reported that findings do not support a protective role of high vitamin D concentration in lymphoid cancers overall. However, they suggest that higher concentrations of vitamin D are associated with a reduced risk of CLL. ${ }^{[14]}$

\section{Figures:-}

\section{AGE WISE DISTRIBUTION OF CML PATIENTS}

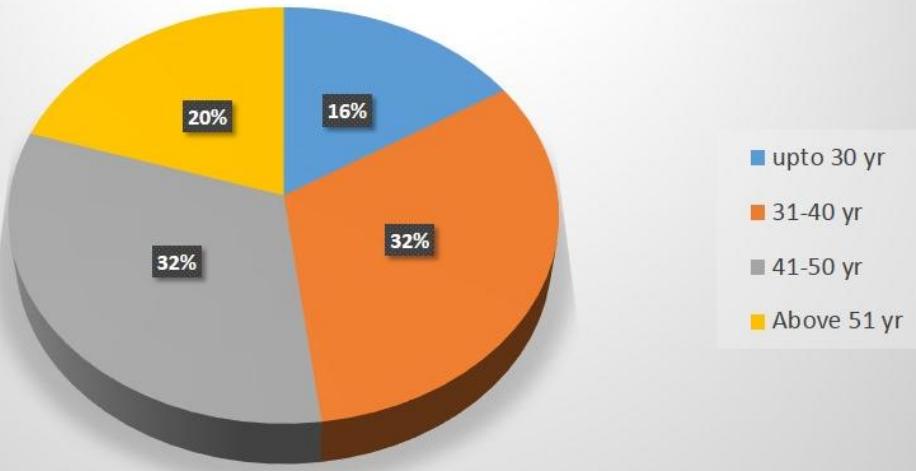

Figure 1: Age wise distribution of CML patients

\section{PATIENT DISTRIBUTION BY SERUM VITAMIN D LEVELS NG/ML}

$=<20=21-30=31-100$

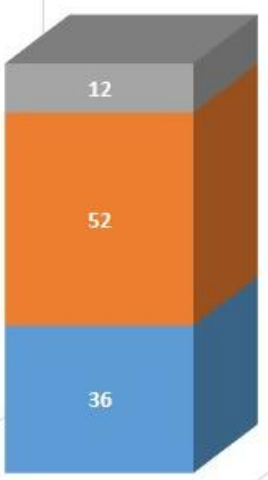

GROUP 1

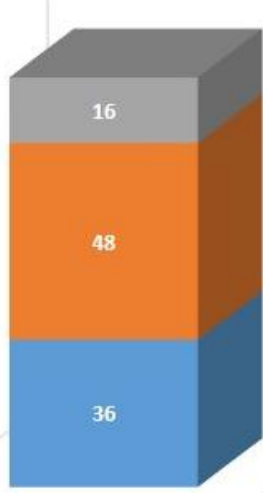

GROUP 2 
Tables:-

Figure 2: Vitamin D levels in CML cases and controls

\begin{tabular}{|l|l|}
\hline \multicolumn{2}{|c|}{ Table I: Reference range for vitamin D serum levels ${ }^{[16]}$} \\
\hline \multicolumn{1}{|c|}{ Levels } & \multicolumn{1}{c|}{ Reference range } \\
\hline Deficient & $<20 \mathrm{ng} / \mathrm{ml}$ \\
\hline Insufficient & 20 to $30 \mathrm{ng} / \mathrm{ml}$ \\
\hline Sufficient & 30 to $100 \mathrm{ng} / \mathrm{ml}$ \\
\hline Intoxication & $>100 \mathrm{ng} / \mathrm{ml}$ \\
\hline
\end{tabular}

\begin{tabular}{|c|c|c|c|}
\hline \multicolumn{4}{|c|}{ Table II: Serum vitamin D levels in males and females } \\
\hline & & Group I & Group II \\
\cline { 3 - 4 } S. vitamin D $(\mathrm{ng} / \mathrm{ml})$ & No. of Patients & Mean \pm SD & Mean \pm SD \\
\hline Females & 13 & $22.52 \pm 6.54$ & $25.23 \pm 10.13$ \\
\hline Males & 12 & $24.37 \pm 9.23$ & $20.0 \pm 6.8$ \\
\hline
\end{tabular}

\begin{tabular}{|c|c|c|c|c|c|c|c|c|}
\hline \multicolumn{9}{|c|}{ Table III: Paired samples t-test } \\
\hline & \multicolumn{5}{|c|}{ Paired Differences } & \multirow[t]{3}{*}{$\mathrm{t}$} & \multirow[t]{3}{*}{ df } & \multirow{3}{*}{$\begin{array}{l}\text { Sig. } \\
(2- \\
\text { tailed })\end{array}$} \\
\hline & \multirow[t]{2}{*}{ Mean } & \multirow[t]{2}{*}{$\begin{array}{c}\text { Std. } \\
\text { Deviation }\end{array}$} & \multirow[t]{2}{*}{$\begin{array}{l}\text { Std. } \\
\text { Error } \\
\text { Mean }\end{array}$} & \multicolumn{2}{|c|}{$\begin{array}{l}\text { 95\% Confidence } \\
\text { Interval of the } \\
\text { Difference }\end{array}$} & & & \\
\hline & & & & Lower & Upper & & & \\
\hline $\begin{array}{l}\text { Vitamin D group I- } \\
\text { VitaminD group II }\end{array}$ & .56880 & 10.84185 & 2.16837 & -3.90649 & 5.04409 & .262 & 24 & .795 \\
\hline
\end{tabular}

\begin{tabular}{|l|l|c|c|c|}
\hline \multicolumn{9}{|c|}{ Table IV: Correlations } \\
\hline \multirow{4}{*}{ Age } & age & VitaminD group I & VitaminD group II \\
\cline { 2 - 5 } & Pearson Correlation & 1 & .150 & $-.464^{*}$ \\
\cline { 2 - 5 } & Sig. (2-tailed) & & .474 & .019 \\
\cline { 2 - 5 } & $\mathrm{N}$ & 25 & 25 & 25 \\
\hline \multirow{5}{*}{ VitaminD group I } & Pearson Correlation & .150 & 1 & .167 \\
\cline { 2 - 5 } & Sig. (2-tailed) & .474 & 25 & .426 \\
\cline { 2 - 5 } & $\mathrm{N}$ & 25 & .167 & 25 \\
\hline \multirow{5}{*}{ VitaminD group II } & Pearson Correlation & $-.464^{*}$ & .426 & 1 \\
\cline { 2 - 5 } & Sig. (2-tailed) & $\mathbf{. 0 1 9}$ & 25 & 25 \\
\cline { 2 - 5 } & $\mathrm{N}$ & 25 & & \\
\hline
\end{tabular}

\section{Conclusion:-}

It may be concluded in that serum vitamin D levels were low in significant number of patients and controls as compared with reference range. Though vitamin D serum levels were low in patients and also in controls significantly, there was no correlation with CML as serum vitamin D levels were also equally low in control groups. However supplementation with vitamin D can alters the outcome of CML patient's needs further confirmation.

\section{Limitations:-}

Larger sample size is required to substantiate the results. Control group should exclude Vit D deficient ones. Mechanisms linking Vitamin D and CML were not elucidated. This needs further studies for exploration.

\section{Conflicts of interest:-None}

\section{Funding:- None}

\section{References:-}

1. Dikshit RP, Nagrani R, Yeole B, Koyande S, Banawali S. Changing trends of chronic myeloid leukemia in greater Mumbai, India over a period of 30 years. Indian J Med PaediatrOncol 2011;32:96-100.

2. Pasternak G, Hochhaus A, Schultheis B, Hehlmann R. Chronic myelogenousleukemia: molecular and cellular aspects. J Cancer Res ClinOncol 1998;124:643-60. 
3. Holick MF. High prevalence of vitamin D inadequacy and implications for health. Mayo Clin Pro 2006;81:353-73.

4. Tanaka H, Abe E, Miyaura C, Kuribayashi T, Konno K, Nishii Y, et al. 1 alpha,25-dihydroxycholecalciferol and a human myeloid leukemia cell line (HL-60). Biochem J 1982;204:713-19.

5. Choudhary A, Chou J, Heller G, Sklar C. Prevalence of vitamin D insufficiency in survivors of childhood cancer. Pediatr Blood Cancer 2013;60:1237-9.

6. Luczynska A, Kaaks R, Rohrmann S, Becker S, Linseisen J, Buijsse B, et al. Plasma 25-hydroxyvitamin D concentration and lymphoma risk: results of the European Prospective Investigation into Cancer and Nutrition. Am J ClinNutr 2013;98:827-38.

7. Zerwekh JE. Blood biomarkers of vitamin D status. Am J ClinNutr 2008;87:1087-91.

8. Holick MF. Vitamin D Status: Measurement, interpretation, and clinical application. Ann Epidemiol 2009;19:73-8.

9. Frazer R, Irvine AE, McMullin MF. Chronic myeloid leukemia in the 21st century. Ulster Med J 2007;76:817.

10. Bansal S, Prabhash K, Parikh P. Chronic myeloid leukemia data from India.Indian J Med PaediatrOncol 2013;34:154-8.

11. Pardanani A, Drake MT, Finke C, Lasho TL, Rozell SA, Jimma T, et al. Vitamin D insufficiency in myeloproliferative neoplasms and myelodysplastic syndromes: clinical correlates and prognostic studies. Am J Hematol 2011;86:1013-6.

12. Simmons JH, Chow EJ, Koehler E, Esbenshade A, Smith LA, Sanders J, et al. Significant 25-hydroxyvitamin D deficiency in child and adolescent survivors of acute lymphoblastic leukemia: treatment with chemotherapy compared with allogeneic stem cell transplant. Pediatr Blood Cancer 2011;56:1114-9.

13. Choudhary A, Chou J, Heller G, Sklar C. Prevalence of vitamin D insufficiency in survivors of childhood cancer. Pediatr Blood Cancer 2013;60:1237-9.

14. Luczynska A, Kaaks R, Rohrmann S, Becker S, Linseisen J, Buijsse B, et al. Plasma 25-hydroxyvitamin D concentration and lymphoma risk: results of the European Prospective Investigation into Cancer and Nutrition. Am J ClinNutr 2013;98:827-38. 